\title{
Synthesis and Characterization of Poly(vinyl chloride-graft- ethylene glycol) Graft Copolymers by "Click" Chemistry
}

\author{
"Click" Kimyası ile Poli(vinil klorür-graft-etilen glikol) Graft \\ Kopolimerlerin Sentezi ve Karakterizasyonu
}

\author{
Research Article \\ Nilgün Asan and Temel Öztürk* \\ Giresun University, Department of Chemistry, Giresun, Turkey.
}

\begin{abstract}
A B S T R AC T
Synthesis of poly(vinyl chloride-g-ethylene glycol) [poly(VC-g-EG)] graft copolymers was carried out by me$S$ ans of "click" chemistry of propargyl polyethylene glycol (propargyl PEG) and terminally azide polyvinyl chloride $\left(P V C-\mathrm{N}_{3}\right.$ ). Primarily propargyl PEG was synthesized by the reaction of PEGs (3000 Da, 2000 Da, 1500 $\mathrm{Da}, 1000 \mathrm{Da}, 600 \mathrm{Da}$, and $400 \mathrm{Da}$ ) with propargyl chloride. PVC-N $\mathrm{N}_{3}$ was obtained by reaction of purified PVC and sodium azide. By using PVC-N $\mathrm{N}_{3}$ and propargyl PEG, poly (VC-g-EG) graft copolymers were synthesized. The primary parameters such as concentration, and time that influenced the reactions were assessed. The characterization of products was accomplished by using multi instruments and methods such as nuclear magnetic resonance spectroscopy, Fourier transform infrared spectroscopy, gel permeation chromatography, elemental analysis, and fractional precipitation [non-solvent (petroleum ether, $\mathrm{mL}$ )/solvent $(\mathrm{THF}, \mathrm{mL})$ ] techniques.
\end{abstract}

\section{Key Words}

"Click" chemistry, graft copolymer, polyvinyl chloride, polyethylene glycol, fractional precipitation.

\section{öz}

oli(vinil klorür-g-etilen glikol) [poli(VC-g-EG)] graft kopolimerlerin sentezi propargil polietilen glikolün (propargil PEG) ve azit son uçlu polivinil klorürün $\left(P \vee C-N_{3}\right.$ ) "click" kimyası vasıtasıyla gerçekleştirildi. Öncelikle propargil PEG, çeşitli molekül ağırlığındaki PEG'ler (3000 Da, 2000 Da, 1500 Da, 1000 Da, 600 Da ve $400 \mathrm{Da}$ ) ile propargil klorürün tepkimesi sonucunda sentezlendi. PVC- $\mathrm{N}_{3}$, saflaştırılmış PVC ve sodyum azit tepkimesi ile elde edildi. Poli(VC-g-EG)] graft kopolimerler, PVC- $\mathrm{N}_{3}$ ve propargil PEG kullanılarak sentezlendi. Derişim ve zaman gibi tepkimeyi etkileyen temel parametreler değerlendirildi. Ürünlerin karakterizasyonları nükleer manyetik rezonans spektroskopisi, Fourier transform infrared spektroskopisi, gel geçirgenlik kromatografisi, elemental analiz ve fraksiyonlu çöktürme [çözücü (THF, $\mathrm{mL}$ )/çöktürücü (petroleum ether, $\mathrm{mL}$ )] gibi yöntemler kullanılarak incelendi.

\footnotetext{
Anahtar Kelimeler

"Click" kimyası, graft kopolimer, polivinil klorür, polietilen glikol, fraksiyonlu çöktürme.
}

Article History: Received: Apr 12, 2016; Revised: Aug 1, 2016; Accepted: Sep 20, 2016; Available Online: Apr 1, 2017.

DOI: 10.15671/HJBC.2017.139

Correspondence to: T. Öztürk, Giresun University, Department of Chemistry, Giresun, Turkey. 


\section{INTRODUCTION}

Click chemistry, a technique offered by - Sharpless et al. [1] in 2001, acts as common synthesis methods and gains popularity in the last few decades. "Click" chemistry includes a set of simple strong linking reactions which have high yields, take minimum purification, and are versatile in participation various structures without the prerequisite of conservation steps [2]. "Click" chemistry applications have been widely studied recently [3-6]. The decent described synthesis of graft copolymers is an important topic in macromolecular chemistry [7]. Graft copolymers which supply particular compositions of physical features are the most appropriate substances for various purposes [8]. Polyvinyl chloride (PVC), one of the most common and important functional polymers, has been kept steady growth of the production and consumption over the world [9]. PVC is less dependent on crude oil or natural gas comparing to all other polymers, which are nonrenewable such as polyethylene, polyethylene terephthalate and polymethyl methacrylate. Block/graft copolymers, having polyethylene glycol (PEG) units, are very appealing substances for chemicals, industrial and biomedical practices, as PEG has unparallel features such superior hydrophilicity, flexibility, ion absorbability, and a superior grade of biocompatibility [10-17].

The synthesis of propargyl polyethylene glycol (propargyl PEG) obtained by reaction of PEG with propargyl chloride were introduced in the present study. After purification of PVC, terminally azide polyvinyl chloride $\left(\mathrm{PVC}-\mathrm{N}_{3}\right)$ was synthesized by using the reaction of PVC with sodium azide $\left(\mathrm{NaN}_{3}\right)$. Propargyl PEG and PVC- $\mathrm{N}_{3}$ were used to obtain poly (vinyl chloride-g-ethylene glycol) [poly (VC-g-EG)] graft copolymers via "click" chemistry. Characterizations of the products were discussed in detail.

\section{MATERIALS and METHODS}

\section{Materials}

PVC (approximately $\mathrm{Mn}=22,000 \mathrm{~g} \cdot \mathrm{mol}^{-1}$ ), $\operatorname{copper}(\mathrm{I})$ bromide (CuBr), N,N-dimethylformamide (DMF), $\mathrm{NaN}_{3}, 2,2$-bipyridyl (bpy), propargyl chloride, and chloroform were received from Sigma-Aldrich, tetrahydrofuran (THF), PEG, ethanol, petroleum ether, and triethylamine were supplied by Merck Millipore and all used as received. Diethyl ether and petroleum ether were received from Carlo Erba Reagent, methanol was supplied by Kimetsan and all used without further purification. The other chemicals were reagent grade and used as supplied.

\section{Instrumentation}

Fourier transform infrared (FTIR) spectra of the products [Figure $1 \mathrm{a}$, Figure $1 \mathrm{~b}$, Figure $1 \mathrm{c}$, Figure $1 \mathrm{~d}$, and Figure $1 \mathrm{e}$ ] were detected using a Perkin Elmer spectrum 100 model FTIR spectrometer. ${ }^{1} \mathrm{H}$-nuclear magnetic resonance ( ${ }^{1} \mathrm{H}-\mathrm{NMR}$ ) spectra of the products [Figure $2 \mathrm{a}$, Figure $2 \mathrm{~b}$, Figure 2 c, Figure $2 \mathrm{~d}$, and Figure 2 e] in deuterated chloroform as the solvent, with tetra methylsilane as internal standard, were detected using a Bruker AVENCE III, ultra-long hold time $400 \mathrm{MHz}$ NMR spectrometer. The molecular weights were determined by Malvern Viscotek RI-UV-GPC max gel permeation chromatography (GPC) with THF as solvent. A calibration curve was composed by using three polystyrene standards: 2.960, 50.400 , and $696.500 \mathrm{Da}$, of low polydispersity. The elemental analyses of the samples were performed on a Costech ECS 4010 instrument.

\section{Purification of PVC}

PVC was purified as the cited literature [18] as follow; $30 \mathrm{~g}$ of it was solved in $120 \mathrm{~mL}$ of THF in 24 hours, and precipitated in methanol and dried under vacuum at $45^{\circ} \mathrm{C}$ for 24 hours before use.

\section{Synthesis of Terminally Azide Polyvinyl Chloride $\left(\mathrm{PVC}-\mathrm{N}_{3}\right.$ )}

The similar procedure described in the cited literatures was applied for synthesis of PVC- $\mathrm{N}_{3}$ $[3,19]$. A fixed quantity of purified PVC, $\mathrm{NaN}_{3}$, and DMF were placed into a flask as shown Table 1. The flask was immersed in an oil bath fixed at 60 OC on a magnetic stirrer, and afterwards nitrogen gas was introduced in the tube by injection with a needle. After fixed time, the flask was opened, and the content was filtered. The solvent was evaporated by using a rotary evaporator. The mixture was drained into excess methanol to separate PVC- $\mathrm{N}_{3}$. The product was dried at room temperature under vacuum for two days. PVC $-\mathrm{N}_{3}$ yield was defined gravimetrically. 
Table 1. Synthesis of PVC- $\mathrm{N}_{3}$ : Reaction temperature: $60^{\circ} \mathrm{C}$.

\begin{tabular}{ccccccc}
\hline Code & $\begin{array}{c}\text { PVC } \\
(\mathrm{g})\end{array}$ & $\begin{array}{c}\mathrm{NaN}_{3} \\
(\mathrm{~g})\end{array}$ & $\begin{array}{c}\mathrm{DMF} \\
(\mathrm{mL})\end{array}$ & $\begin{array}{c}\text { Time } \\
(\text { hour })\end{array}$ & $\begin{array}{c}\text { Yield } \\
(\mathrm{g})\end{array}$ & $\begin{array}{c}\text { Conversion } \\
(\text { wt \%) }\end{array}$ \\
\hline NG-1 & 10.003 & 0.350 & 140 & 96 & 9.600 & 92.72 \\
\hline NG-2 & 4.001 & 0.118 & 50 & 98 & 3.945 & 95.77 \\
\hline NG-3 & 12.058 & 0.510 & 143 & 96 & 12.025 & 95.68 \\
\hline
\end{tabular}

Table 2. Synthesis of propargyl PEG. Reaction temperature: $25^{\circ} \mathrm{C}$.

\begin{tabular}{|c|c|c|c|c|c|c|c|}
\hline Code & PEG (g) & $\begin{array}{l}\text { Propargyl } \\
\text { chloride (g) }\end{array}$ & $\begin{array}{l}\text { Triethylamine } \\
\text { (g) }\end{array}$ & $\begin{array}{l}\text { Chloroform } \\
(\mathrm{mL})\end{array}$ & $\begin{array}{l}\text { Time } \\
\text { (hour) }\end{array}$ & $\begin{array}{l}\text { Yield } \\
(\mathrm{g})\end{array}$ & $\begin{array}{c}\text { Conversion } \\
\text { (wt \%) }\end{array}$ \\
\hline$N N-1$ & $\begin{array}{c}5.007 \\
(\text { PEG-3000 Da) }\end{array}$ & 0.119 & 0.182 & 35 & 57 & 4.189 & 87.10 \\
\hline NN-2 & $\begin{array}{c}15.002 \\
(\text { PEG-2000 Da) }\end{array}$ & 1.118 & 0.835 & 45 & 54 & 14.750 & 83.42 \\
\hline$N N-3$ & $\begin{array}{c}7.501 \\
(\text { PEG-1500 Da) }\end{array}$ & 0.373 & 0.557 & 40 & 48 & 7.025 & 83.34 \\
\hline$N N-4$ & $\begin{array}{c}10.076 \\
(\text { PEG-1000 Da) }\end{array}$ & 0.745 & 1.113 & 42 & 48 & 7.369 & 63.14 \\
\hline$N N-5$ & $\begin{array}{c}10.028 \\
(\mathrm{PEG}-600 \mathrm{Da})\end{array}$ & 1.245 & 1.837 & 43 & 49 & 10.750 & 82.00 \\
\hline$N N-6$ & $\begin{array}{c}10.101 \\
(\mathrm{PEG}-400 \mathrm{Da})\end{array}$ & 1.882 & 2.811 & 42 & 53 & 10.938 & 73.93 \\
\hline
\end{tabular}

\section{Synthesis of Propargyl Polyethylene Glycol} (Propargyl PEG)

The similar procedure reported in the cited literature was followed for synthesis of propargyl PEGs by using PEG with 600 Da and PEG with 1000 Da [19]. Specified amounts of PEGs (3000 Da, $2000 \mathrm{Da}, 1500 \mathrm{Da}, 1000 \mathrm{Da}, 600 \mathrm{Da}$, and 400 $\mathrm{Da}$ ) in fixed amounts of chloroform was mixed with certain amounts of triethylamine as shown Table 2 . The solution was transported into a $250 \mathrm{~mL}$ schlenk flask with a magnet and a nitrogen gas input. The flask was cooled down to below $0^{\circ} \mathrm{C}$ and nitrogen gas was injected into the flask. This solution was added certain amounts of propargyl chloride in $5 \mathrm{~mL}$ of chloroform via a dropping funnel for the duration of half an hour. The solution was stirred for half an hour at down to below $0^{\circ} \mathrm{C}$. Afterwards, the mixture was slowly warmed to room temperature and the reaction was terminated. After fixed times, solvent was partially evaporated and the residue precipitated in cold diethyl ether. The product was kept in a refrigerator overnight. After decantation, the product was dried at room temperature under vacuum for two days. The yield of propargyl PEG was defined gravimetrically.

\section{Synthesis of Poly (VC-g-EG) Graft Copolymers by "Click" Chemistry}

The "click" chemistry was carried out by Bakker et al. [19] on the tip of Ostec electrode with installed membrane immersed in the reaction mixture by using the PVC membrane including azide groups, clickable tetraethylene glycol (or PEG 600, or PEG 1000, or clickable dicysteine), $\mathrm{CuSO}_{4} \cdot 5 \mathrm{H}_{2} \mathrm{O}$ and ascorbic acid. Poly (VC-g-EG) was synthesized by "click" chemistry in the present study. Specified amounts of PVC- $\mathrm{N}_{3}$, propargyl PEGs, CuBr, bpy, and THF (as solvent) were charged separately into a $250 \mathrm{~mL}$ schlenk flask, then, nitrogen gas was injected in the tube for five minutes in according to "click" chemistry mechanism. The flask was immersed in an oil bath thermostated at $35^{\circ} \mathrm{C}$ for 
Table 3. Synthesis of poly (VC-g-EG) graft copolymers by "click" chemistry. Reaction temperature: $35^{\circ} \mathrm{C}$, non-solvent (petroleum ether, $\mathrm{mL}) /$ solvent $(\mathrm{THF}, \mathrm{mL})$.

\begin{tabular}{|c|c|c|c|c|c|c|c|c|c|c|c|}
\hline Code & $\begin{array}{c}\text { Propargyl } \\
\text { PEG (g) }\end{array}$ & $\begin{array}{l}\mathrm{PVC}-\mathrm{N}_{3} \\
\text { (g) }\end{array}$ & $\begin{array}{l}\mathrm{CuBr} \\
(\mathrm{g})\end{array}$ & $\begin{array}{l}\text { bpy } \\
\text { (g) }\end{array}$ & $\begin{array}{l}\text { THF } \\
(\mathrm{mL})\end{array}$ & $\begin{array}{l}\text { Time } \\
\text { (hour) }\end{array}$ & $\gamma^{*}$ & $\begin{array}{l}\text { Yield } \\
\text { (g) }\end{array}$ & $\begin{array}{c}\text { Conversion } \\
\text { (wt \%) }\end{array}$ & $\mathrm{Mn}, \mathrm{GPC}$ & $\mathrm{Mw} / \mathrm{Mn}$ \\
\hline$N L-1$ & $\begin{array}{c}1.364 \\
\text { (NN-1 in } \\
\text { Table 2) }\end{array}$ & 1.000 & 0.065 & 0.140 & 30 & 27 & 0.70 & 1.628 & 68.87 & 36,306 & 1.63 \\
\hline$N L-2$ & $\begin{array}{l}2.768 \\
\text { (NN-2 in } \\
\text { Table 2) }\end{array}$ & 3.045 & 0.199 & 0.432 & 40 & 25 & 0.69 & 4.987 & 85.80 & - & - \\
\hline$N L-3$ & $\begin{array}{l}1.364 \\
(\text { NN-3 in } \\
\text { Table 2) }\end{array}$ & 2.004 & 0.131 & 0.284 & 33 & 24 & 0.72 & 2.111 & 62.70 & 40,309 & 1.32 \\
\hline$N L-4$ & $\begin{array}{l}0.504 \\
\text { (NN-4 in } \\
\text { Table 2) }\end{array}$ & 1.133 & 0.072 & 0.156 & 30 & 24 & 0.72 & 1.222 & 74.62 & 32,837 & 1.67 \\
\hline$N L-5$ & $\begin{array}{l}0.508 \\
(\mathrm{NN}-5 \text { in } \\
\text { Table 2) }\end{array}$ & 2.005 & 0.130 & 0.283 & 35 & 26 & 0.71 & 2.145 & 85.36 & 29.876 & 3.06 \\
\hline$N L-6$ & $\begin{array}{l}0.370 \\
\text { (NN-6 in } \\
\text { Table 2) }\end{array}$ & 2.043 & 0.129 & 0.281 & 35 & 24 & 0.63 & 1.961 & 81.26 & 24.048 & 3.23 \\
\hline
\end{tabular}

specific times. After the polymerization, the flask content was filtered. Solvent was partly moved away by using a rotary evaporator. The mixture was drained into excess methanol to separate poly (VC-g-EG) graft copolymer. The polymers were dried at room temperature under vacuum for two days. The conversion of graft copolymer was defined gravimetrically (Table 3).

Fractional Precipitation of the Graft Copolymers Fractional precipitations $(\gamma)$ of the polymers were determined by following to the process stated in the literatures [17,20-22]. Vacuum dried polymer sample (about $0.1 \mathrm{~g}$ ) was solved in $10 \mathrm{~mL}$ THF. Petroleum ether was added as drop wise to $5 \mathrm{~mL}$ of the solution with mixing until turbidity forms, and then 1-2 $\mathrm{mL}$ petroleum ether was added to complete the precipitation. The precipitate was moved away by filtration. The solvent was THF and the nonsolvent was petroleum ether. In this solventnonsolvent system, the $\gamma$ values were determined as the ratios of total volume of nonsolvent used for first fraction to volume of solvent used.

The nonsolvent addition into the filtrate solution was proceeded in according to the same

$$
\gamma_{\text {value }}=\frac{\text { Volume of Nonsolvent, } \mathrm{mL} \text { (petroleum ether) }}{\text { Volume of Solvent, } \mathrm{mL}(\mathrm{THF})}
$$

process talk about above to define the $\gamma$ value for the second fraction if there is.

\section{RESULTS and DISCUSSION}

\section{Synthesis of PVC- $\mathrm{N}_{3}$}

PVC- $\mathrm{N}_{3}$ was synthesized by using purified PVC (FTIR in Figure 1a: $2863-2974 \mathrm{~cm}^{-1}$ for aliphatic $\mathrm{CH}_{2}$ and $-\mathrm{CH}$ groups; ${ }^{1} \mathrm{H}-\mathrm{NMR}$ in Figure $2 \mathrm{a}: 2.2$ ppm for $-\mathrm{CH}_{2}$ and $4.4 \mathrm{ppm}$ for $-\mathrm{CHCl}$ protons) and $\mathrm{NaN}_{3}$. PVC- $\mathrm{N}_{3}$ yield was between 92.72 wt \% and 95.77 wt \% (Table 1). The first line in Scheme 1 includes the reaction pathway for synthesis of PVC $-\mathrm{N}_{3}$. The FTIR spectrum of PVC- $\mathrm{N}_{3}$ in Figure 1b shows $2926 \mathrm{~cm}^{-1}$ and $2880 \mathrm{~cm}^{-1}$ for aliphatic $\mathrm{CH}_{2}$ and $-\mathrm{CH}$ groups, and and $2300 \mathrm{~cm}^{-1}$ for $-\mathrm{N}_{3}$ groups. Typical $-\mathrm{N}_{3}$ signal at $2300 \mathrm{~cm}^{-1}$ appeared in polymer sample, which was confirmed the expected chemical structure. The ${ }^{1} \mathrm{H}-\mathrm{NMR}$ spectrum of PVC- $\mathrm{N}_{3}$ in Figure $2 \mathrm{~b}$ shows $2.2 \mathrm{ppm}$ for $-\mathrm{CH}_{2}$ protons, $3.0 \mathrm{ppm}$ for $-\mathrm{CHN}_{3}$ protons, and $4.3 \mathrm{ppm}$ for $-\mathrm{CHCl}$ protons. 


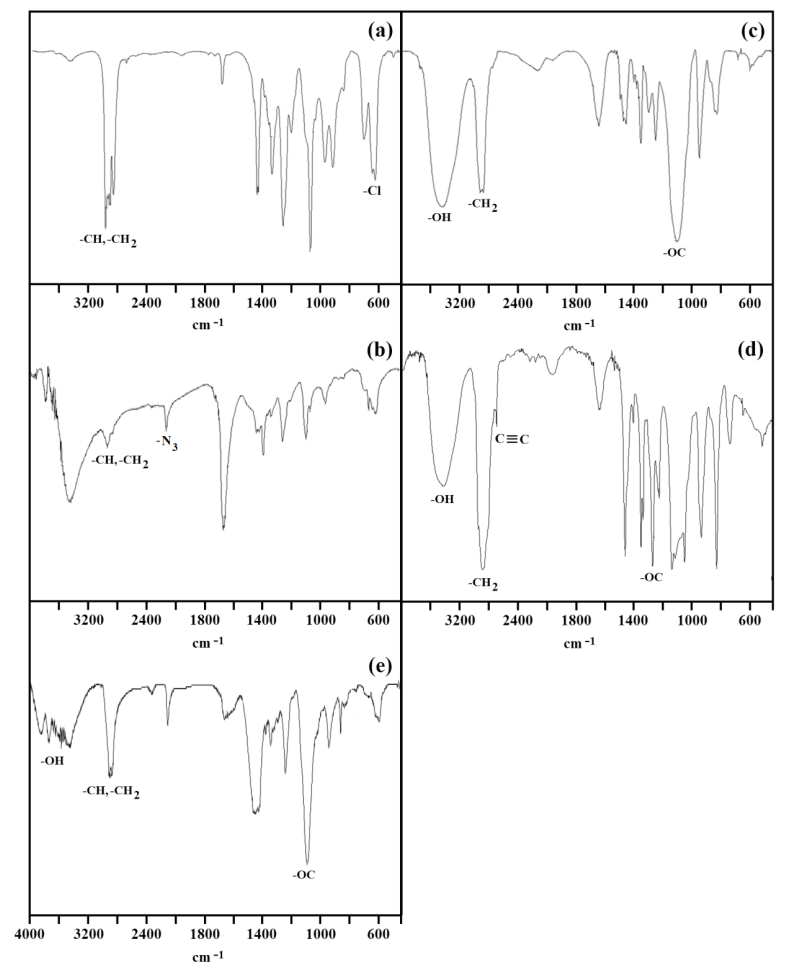

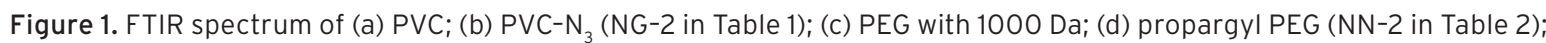
and (e) poly (VC-g-EG) graft copolymer (NL-2 in Table 3).

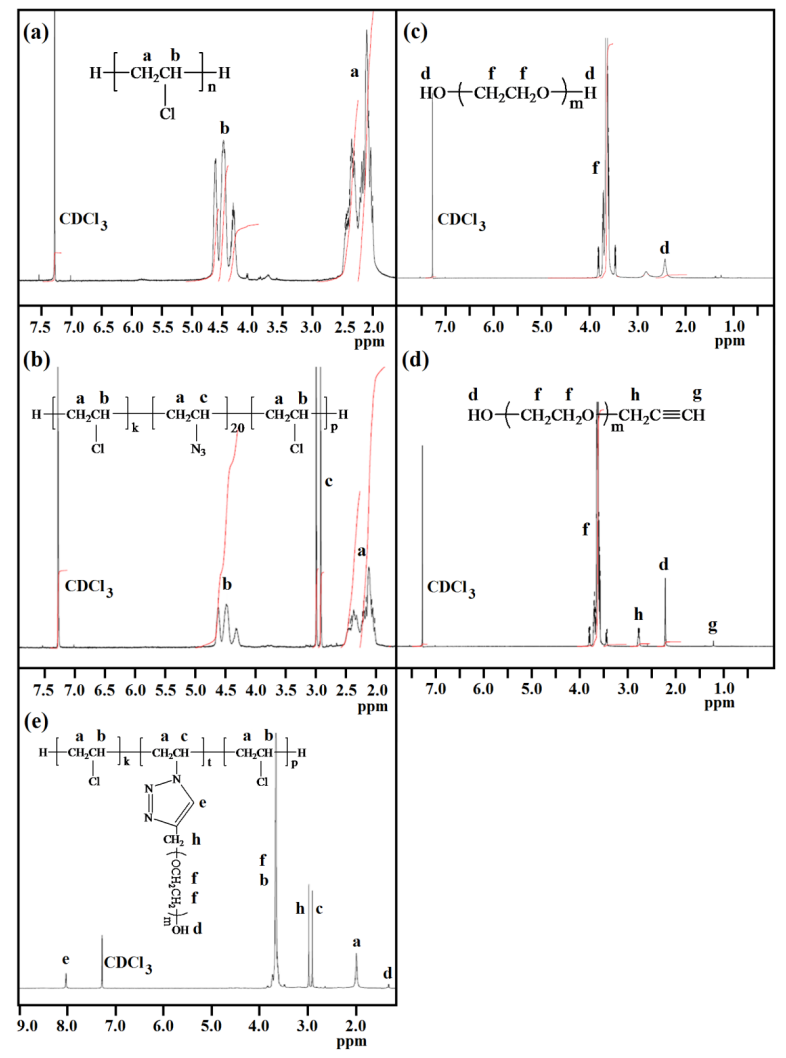

Figure 2. ${ }^{1} \mathrm{H}-\mathrm{NMR}$ spectra of (a) PVC; (b) PVC-N $(\mathrm{NG}-3$ in Table 1); (c) PEG with 3000 Da; (d) propargyl PEG (NN-2 in Table 2); and (e) poly (VC-g-EG) graft copolymer (NL-2 in Table 3). 


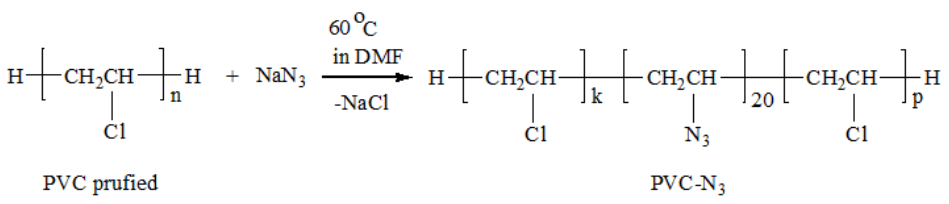

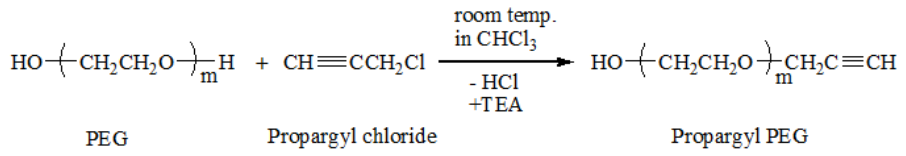

Scheme 1. Reaction pathways in the synthesis of PVC-N $\mathrm{N}_{3}$ and propargyl PEG.

The results of elemental analysis of NG-1 in Table 1 show 39.98 wt $\%$ C, 5.98 wt $\% \mathrm{H}$, and 1.49 wt $\% \mathrm{~N}$. The results of elemental analysis of NG-2 in Table 1 show 39.62 wt \% C, 6.00 wt \% H, and $3.91 \mathrm{wt} \% \mathrm{~N}$. The number of azide groups which is present for modification with chloride groups was determined by using $3.91 \mathrm{wt} \% \mathrm{~N}$ (for NG-2) acquired and $\mathrm{Mn}$ value of PVC- $\mathrm{N}_{3}$ (approximately 22,000 g.mol ${ }^{-1}$ ). It was calculated about 20 azide groups per chain.

\section{Synthesis of Propargyl PEG}

Propargyl PEG was synthesized by using PEGs with different molecular weights (FTIR-Figure 1c: $3450 \mathrm{~cm}^{-1}$ for $-\mathrm{OH}, 2850 \mathrm{~cm}^{-1}$ for aliphatic $-\mathrm{CH}_{2}$ and $1100 \mathrm{~cm}^{-1}$ for -OC groups; ${ }^{1} \mathrm{H}-\mathrm{NMR}-$ Figure $2(\mathrm{c})$ : $2.4 \mathrm{ppm}$ for $-\mathrm{OH}$, and $3.7 \mathrm{ppm}$ for $-\mathrm{OCH}_{2}$ protons) and propargyl chloride. Propargyl PEG yield was between 63.14 wt.\% and 87.10 wt.\% (Table 2). Maximum yield of propargyl PEG was obtained by using PEG with 3000 Da. Minimum yield of propargyl PEG was obtained by using PEG with $1000 \mathrm{Da}$. The second line in Scheme 1 includes the reaction pathway for synthesis of propargyl PEG. It is more probably that there will be a population of three types of PEG which possess zero, one, and two propargyl end groups. As we used [propargyl chloride $] /[\mathrm{PEG}]=1 / 1(\mathrm{~mol} / \mathrm{mol})$ in the reaction, we think that there could be zero and two propargyl end groups at very little amounts. To the best of our knowledge, the large quantity propargyl PEG has been obtained with a propargyl group in the chain end as we are used $1 / 1(\mathrm{~mol} / \mathrm{mol})$ ratio to synthesize propargyl PEG. The other propargyl PEG possessed two propargyl functions could be acquired at the little quantities in the chain end. We are taking into account of propargyl PEG having a hydroxyl function and propargyl function for synthesis of the graft copolymer. The FTIR spectrum of propargyl PEG in Figure 1d indicates the characteristic signals at $3450 \mathrm{~cm}^{-1}$ for $-\mathrm{OH}$ groups, $2850 \mathrm{~cm}^{-1}$ for aliphatic $-\mathrm{CH}_{2}$ groups, 2700 $\mathrm{cm}^{-1}$ for $\mathrm{C} \equiv \mathrm{C}$ groups, and $1270 \mathrm{~cm}^{-1}$ for $-O C$ groups. The ${ }^{1} \mathrm{H}-N M R$ spectrum of the product in Figure $2 \mathrm{~d}$ also shows $1.3 \mathrm{ppm}$ for $-\mathrm{CH}$ protons, $2.3 \mathrm{ppm}$ for - $\mathrm{OH}$ protons, $2.8 \mathrm{ppm}$ for $-\mathrm{OCH}_{2}$ protons linked PEG block, $3.7 \mathrm{ppm}$ for $-\mathrm{OCH}_{2}$ protons of PEG block.

\section{Synthesis of the Graft Copolymers by "Click" Chemistry}

Poly(VC-g-EG) graft copolymers were synthesized at $35^{\circ} \mathrm{C}$ temperature by using "click" chemistry of propargyl PEG with different molecular weight and PVC $-\mathrm{N}_{3}$. The results of graft polymerization are shown in Table 3. The conversion obtained from weight of copolymer was between $62.70 \mathrm{wt} \%$ and $85.80 \mathrm{wt} \%$. High conversions were relatively obtained by "click" chemistry of propargyl PEG and PVC $-\mathrm{N}_{3}$. Maximum yield of the graft copolymer was obtained by using propargyl PEG (NN-2 in Table 2) synthesized using PEG with 2000 Da. Minimum yield of the graft copolymer was obtained by using propargyl PEG (NN-3 in Table 2) synthesized using PEG with $1500 \mathrm{Da}$. Scheme 2 contains the outline for synthesis of graft copolymer. Polydispersity index of the graft copolymers are between 1.32 and 3.23. Because of use of PVC, Mw/Mn values of the graft copolymers are relatively higher than expected. Figure 3 shows the unimodal GPC curves of graft copolymers (NL-1, and NL-4 in Table 3). Increases in the molecular weights of copolymers as compared with molecular weights of reactants can approve formation of graft copolymer. It can be observed poly (VC-g-EG) graft copolymers are relatively soft-rigid as $P V C$ is rigid and PEG is soft. The FTIR spectrum of poly (VC-g-EG) graft copolymer in Figure 1e shows the signals at 3838 $\mathrm{cm}^{-1}$ for $-\mathrm{OH}$ groups, $3446 \mathrm{~cm}^{-1}$ for aromatic $-\mathrm{CH}$ 


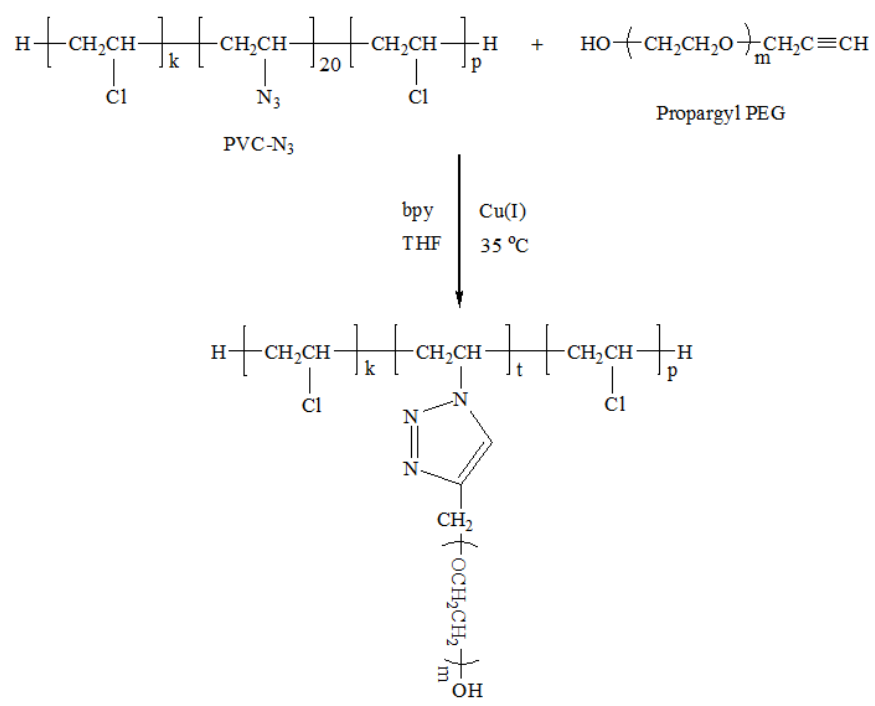

Poly(vinyl chloride-g-ethylene glycol) graft copolymer

Scheme 2. Reaction pathways in the synthesis of poly (VC-g-EG) graft copolymer.

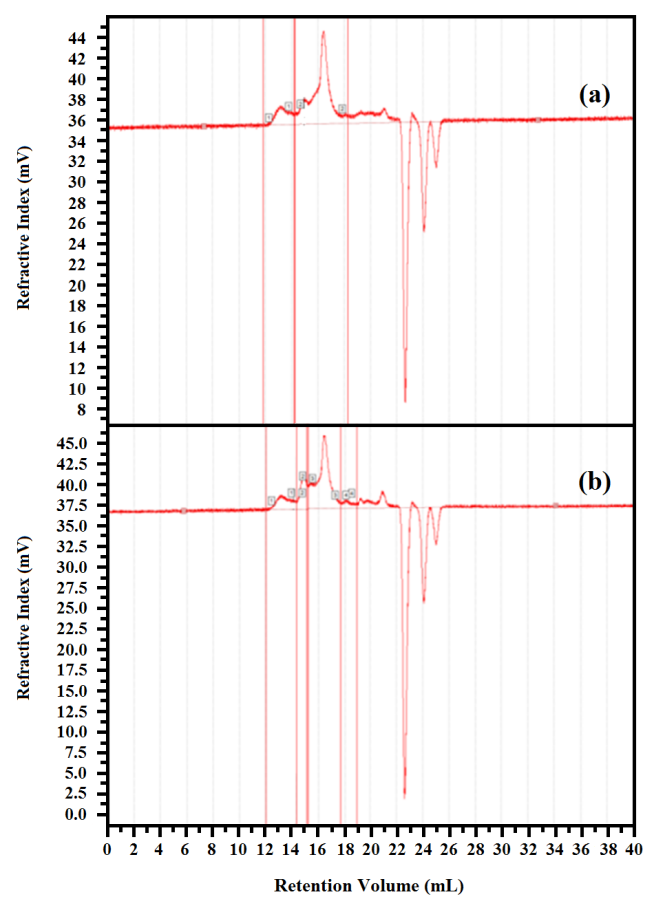

Figure 3. GPC curves of the graft copolymers. (a) NL-1, and (b) NL-4 in Table 3.

group of triazole group, $2904 \mathrm{~cm}^{-1}$ and $2872 \mathrm{~cm}^{-1}$ for aliphatic $-\mathrm{CH}$ and $-\mathrm{CH}_{2}$ groups, $1100 \mathrm{~cm}^{-1}$ for -OC groups, and $682 \mathrm{~cm}^{-1}$ for $-\mathrm{Cl}$ groups. Typical ${ }^{1} \mathrm{H}-\mathrm{NMR}$ spectra of the graft copolymers in Figure 2(e) shows $8.0 \mathrm{ppm}$ for aromatic $-\mathrm{CH}$ proton of triazole group, $3.7 \mathrm{ppm}$ for $-\mathrm{OCH}_{2}$ protons of $\mathrm{PEG}$ group and $-\mathrm{CICH}$ protons of PVC group, $3.0 \mathrm{ppm}$ for $-\mathrm{OCH}_{2}$ protons linked triazole group, $2.9 \mathrm{ppm}$ for $-\mathrm{NCH}_{2}$ protons linked PEG and triazole groups, $1.9 \mathrm{ppm}$ for $-\mathrm{CH}_{2}$ protons of PVC group, and 1.3 $\mathrm{ppm}$ for $-\mathrm{OH}$. The observed peak at $8.0 \mathrm{ppm}$ for aromatic $-\mathrm{CH}$ proton of triazole group was evidence which the graft copolymer was obtained. 


\section{Fractional Precipitation}

The $\gamma$ values of poly (VC-g-EG) graft copolymers were between 0.63 and 0.72 . In the solventnonsolvent method, $\gamma$ values were obtained 1.10-1.22 for homo-PVC [18], and 0.25-0.35 for homo-PEGs (3000 Da, $2000 \mathrm{Da}, 1500 \mathrm{Da}, 1000$ $\mathrm{Da}, 600 \mathrm{Da}$, and $400 \mathrm{Da}$ ). The $\gamma$ values of graft copolymers are varied between those of homoPVC and homo-PEG. Fractional precipitation behavior gives another evidence for the creation of graft copolymer. It can also be concluded that homopolymer formation is not available because no polymer precipitation is acquired at the $\gamma$ values of related homopolymers.

\section{CONCLUSIONS}

A set of synthesis, "click" chemistry conditions of the graft copolymers, were achieved. The graft copolymers were relatively acquired in high yield and molar weight. The proposed procedure for the synthesis of graft copolymers is simple and efficient. The characterization of graft copolymers was accomplished by using ${ }^{1} \mathrm{H}-\mathrm{NMR}$ spectroscopy, FTIR spectroscopy, GPC, elemental analysis, and fractional precipitation techniques.

\section{ACKNOWLEDGMENTS}

This work was supported by Giresun University Research Fund (grand number: FEN-BAP-A-250414-58).

\section{References}

1. H.C. Kolb, M.G. Finn, K.B. Sharpless, Click chemistry: diverse chemical function from a few good reactions, Angew. Chem. Int. Ed., 40 (2001) 2004-2021.

2. C.D. Hein, X.M. Liu, D. Wang, Click chemistry, a powerful tool for pharmaceutical sciences, Pharm. Res., 25 (2008) 2216-2230.

3. B. Kiskan, G. Demiray, Y. Yagci, Thermally curable polyvinyl chloride via click chemistry, J. Polym. Sci. Part A: Polym. Chem., 46 (2008) 3512-3518.

4. D.Y. Zhu, G.S. Cao, W.L. Qiu, M.Z. Rong, M.Q. Zhang, Self-healing polyvinyl chloride (PVC) based on microencapsulated nucleophilic thiol-click chemistry, Polymer, (69) 2015 1-9.

5. D. Tunc, B. Gacal, Y. Yagci, An amphiphatic thioxanthone-anthracene photoinitiator for freeradical polymerization, Turk. J. Chem., 37 (2013) 525-537.

6. J. Xu, J. Ye, S.Y. Liu, Synthesis of well-defined cyclic poly(N-isopropylacrylamide) via click chemistry and its unique thermal phase transition behavior, Macromolecules, 40 (2007) 9103-9110.

7. N. Stoeckel, P.C. Wieland, O. Nuyken, New syntheses of graft copolymers using the DPE-technique: ATRP graft copolymerization, Polym. Bull., 49 (2002) 243250.
8. T. Öztürk, M.N. Atalar, M. Göktaş, B. Hazer, One-step synthesis of block-graft copolymers via simultaneous reversible-addition fragmentation chain transfer and ring-opening polymerization using a novel macroinitiator, J. Polym. Sci. Part A: Polym. Chem., 51 (2013) 2651-2659.

9. D.F. Grishin, Synthesis of vinyl chloride homo- and copolymers under the conditions of controlled radical polymerization, Russ. J. Appl. Chem., 88 (2015) 361376.

10. N. Hadjichristidis, H. latrou, M. Pitsikalis, J. Mays, Macromolecular architectures by living and controlled/living polymerizations, J. Prog. Polym. Sci., 31 (2006) 1068-1132.

11. H. Wang, J.H. Dong, A.Y. Qiu, Z.W. Gu, Studies on properties and drug delivery systems of PTMC- $b$ PEG-b-PTMC block copolymers, J. Macromol. Sci. Part A: Pure Appl. Chem., A 35 (1998) 811-820.

12. M. Aydinli, M. Tutas, O.A. Bozdemir, Mechanical and light transmittance properties of locust bean gum based edible films, Turk. J. Chem., 28 (2004) 163-171.

13. R.S. Velichkova, D.C. Christova, Amphiphilic polymers from macromonomers and telechelics, Prog. Polym. Sci., 20 (1995) 819-887.

14. G. Riess, Micellization of block copolymers, Prog. Polym. Sci., 28 (2003) 1107-1170.

15. B. Gacal, H. Durmaz, M.A. Tasdelen, G. Hizal, U. Tunca, Y. Yagci, A.L. Demirel, Anthracene-maleimide-based Diels-Alder "click chemistry" as a novel route to graft copolymers, Macromolecules, 39 (2006) 5330-5336.

16. S. Pispas, N. Hadjichristidis, Aggregation behavior of poly(butadiene-b-ethylene oxide) block copolymers in dilute aqueous solutions: effect of concentration, temperature, ionic strength, and type of surfactant, Langmuir, 19 (2003) 48-54.

17. M. Göktaş, T. Öztürk, M.N. Atalar, A.T. Tekeş, B. Hazer, One-step synthesis of triblock copolymers via simultaneous reversible-addition fragmentation chain transfer (raft) and ring-opening polymerization using a novel difunctional macro-raft agent based on polyethylene glycol, J. Macromol. Sci. Part A: Pure Appl. Chem., 51 (2014) 854-863.

18. T. Öztürk, M. Göktaş, B. Savaş, M. Işıklar, M.N. Atalar, B. Hazer, Synthesis and characterization of poly(vinyl chloride-graft-2-vinylpyridine) graft copolymers using a novel macroinitiator by reversible additionfragmentation chain transfer polymerization, ePolymers, 14 (2014) 27-34.

19. M. Pawlak, E. Grygolowicz-Pawlak, G.A. Crespo, G. Mistlberger, E. Bakker, Pvc-based ion-selective electrodes with enhanced biocompatibility by surface modification with "click" chemistry, Electroanalysis, 25 (2013) 1840-1846.

20. B. Hazer, B. Erdem, R.W. Lenz, Styrene polymerization with some new macro or macromonomeric azoinitiators having peg units, J. Polym. Sci. Part A: Polym. Chem., 32 (1994) 1739-1746.

21. T. Öztürk, M. Yavuz, M. Göktaş, B. Hazer, Onestep synthesis of triarm block copolymers by simultaneous atom transfer radical and ring-opening polymerization, Polym. Bull., 73 (2016) 1497-1513.

22. T. Öztürk, O. Kayğın, M. Göktaş, B. Hazer, Synthesis and characterization of graft copolymers based on polyepichlorohydrin via reversible additionfragmentation chain transfer polymerization, J. Macromol. Sci. Part A: Pure Appl. Chem., 53 (2016) 362-367. 